NGTT Deel 54, Nommers $3 \& 4$, September en Desember 2013

Van Wyngaard, Cobus

University of South Africa

\title{
The church as alternative community and the struggle for liberation in the work of David Bosch
}

\begin{abstract}
The church as alternative community remains a key aspect in understanding the work of David Bosch, while some of the most important critique of his work emerged from liberation theology. By exploring Bosch's use of the relationship between Jesus and the Zealots in his reflection on the alternative community, the article will argue that Bosch not only sees his own work as standing close to that of liberation theologians, but also that Bosch worked with a very narrow interpretation of liberation theology. Also under discussion are some aspects of what Bosch believed the role of this alternative community should have been amidst apartheid, while the lack of concrete analysis for how this might contribute to the liberation of people is emphasized.
\end{abstract}

\section{INTRODUCTION}

When remembering Reformed theology and the struggle against apartheid, little justification for revisiting the work of David Bosch seems necessary. In Bosch's own words, apartheid was "nothing but a heresy" (Bosch 1983a), and his choice to turn down various attractive posts internationally because of his personal commitment to the struggle against apartheid is wellknown (Kritzinger \& Saayman 2011: 142-143).

The notion of the church as "alternative community" was a central theme in the work of Bosch and was also directly related to his own response to apartheid. This was what he chose to reflect upon when the Journal of Theology for Southern Africa asked him to write an article on how his own theology had developed during the decade between 1972 and 1982 (Bosch 1982a). The centrality of this notion in his work has long been recognized, and continues to be reflected upon in recent publications (Bekele, 2011; Kritzinger \& Saayman 2011; Reppenhagen \& Guder 2011; Saayman 2011; Van Wyngaard 2011). However, the choice to remember and reflect on the alternative community in the work of David Bosch perhaps also illustrates the growing interest in seeing the church as a counter-cultural or alternative community (Reppenhagen \& Guder, 2011: 550-551).

Central to attempts at remembering David Bosch in relation to the struggle for justice in South Africa is the debate concerning his response to liberation theology. While this can be seen in the response to the work of Bosch preceding the publication of Transforming mission (Balcomb 1989; Nicol 1990), it is still evident in recent contributions (Botha 2011; Conradie 2011; Kritzinger \& Saayman 2011), and is of particular interest in this article. This relates directly to his reflection on the church as alternative community (Reppenhagen and Guder 2011:540).

I will provide an introduction to Bosch's understanding of the church as alternative community by exploring one key analogy in his thinking on the topic, namely the relation between Jesus and the Zealots. This analogy will be used to discuss the relationship between 
NGTT: Oopbron - http://ngtt.journals.ac.za

Bosch's alternative community and liberation theology, emphasizing both Bosch's affinity to and distance from liberation theology. Lastly, some key aspects of the church as alternative community will be explored in considering whether the alternative community can effect social change.

\section{JESUS AND THE ZEALOTS}

The alternative community is a multifaceted notion in Bosch's writings. While it is clearly influenced and formed by his appreciation of the Mennonites, and in particular John Howard Yoder (Kritzinger \& Saayman 2011: 77), he simultaneously attempts to describe the alternative community in ways that are in line with Reformed (1979: 222-226) and Catholic theology (Bosch 1991b:373-376). While some of the metaphors Bosch uses clearly reflect his Anabaptist connection (such as that of the church as antibody), other metaphors attempt to sketch a more ecumenical interpretation of the church as alternative community (such as the church as the new community).

The argument that Bosch possibly repeats most often when describing the church as alternative community, concerns four models he identifies in the various groups around Jesus. It is an argument which in both its structure and content is borrowed from Yoder (1972: 18-31), yet at key points also seems to draw from Cullmann (1970), as will be pointed out below. In a typical form of this argument, Bosch $(1975 ; 1977 a ; 1981 ; 1982 b)$ identifies four Jewish groups in the time of Jesus that approached the current social reality in various ways. He describes all of these as simultaneously political and religious. Furthermore, he broadly states that these are the same options available to us today, and sometimes draws links between these groups and the options from which the church can choose today. Mostly these are broad references to various theological traditions, but sometimes he is quite specific about how he identifies these groups within the South African context.

The first option available to Jesus is that of the Sadducees. They followed a theology of the status quo, accepting the Roman rule. It was a form of political realism; they knew that the Roman rule could not be overthrown. But such realism easily developed into maintaining the status quo.

The second option is that of the Pharisees, who despised the Sadducees because of their involvement with politics. Bosch regularly describes them as the pietists of their day. They busied themselves with that which was purely religious, the classification of the whole of life into what was clean and unclean. This option advocates a purely religious ministry that steers clear of politics.

The third option is that of the Essenes who withdrew from public life to seclude themselves within a faithful community, waiting for the final judgment of God. Theirs is a theology of the ghetto, a theology of asceticism.

Perhaps a short interlude is appropriate before continuing to the fourth group. Bosch describes the pietism of the churches in South Africa as contributing to the problem of apartheid: The evangelical churches and African Independent churches who teach that governmental authority is from God, and white churches excluding socio-political demands from their faith (1987:10-11). The Dutch Reformed church could simultaneously be described as a classic example of a theology of the status quo while also reflecting a strong pietist identity (1983b:1- 
NGTT Deel 54, Nommers $3 \& 4$, September en Desember 2013

2). I want to spend more time on the fourth group, which I believe can help in illuminating the tension within Bosch's own struggle for justice, as well as reintroduce an important tension in the remembrance of Bosch today.

The fourth group he identifies is that of the Zealots, ${ }^{1}$ an underground political movement, directly opposed to the Sadducees. They answered the Roman force with force; they were the freedom fighters of the day. They represented a theology of revolution, and identified the reign of God with institutional reform. Bosch often reminds that Jesus was closer to this group than to the other three (Bosch 1975:4; 1981:7; 1982b:7), an aspect not reflected upon in summaries of how Bosch used this argument (see Ahonen 2003:106; Bekele 2011:304-306). In his argument he then presents Jesus as an alternative also in relation to the Zealots, but the emphasis on the relatedness between Jesus and the Zealots in the work of Bosch deserves attention. Both Cullmann and Yoder emphasize the similarities between Jesus and the Zealots, and by pointing out the differences use this to clarify how Jesus responded to particular political questions.

Yoder's Jesus calls for a radical transformation of society, but argues that the pacifist position is the only true way to bring about this transformation. He stresses that in its essence Jesus' difference with the Zealots not only concerns their instrument of bringing about change, but that the new order brought about by the sword is not the new peoplehood of God. What Jesus seeks is a more radical liberation than what the Zealots were seeking, one which breaks with the cycle of violence (Yoder 1972:23-24; Bosch 1982:5). In a slightly different way Cullmann formulates the difference between Jesus and the Zealots as a difference of both method and goal (Cullmann 1970:44). The difference in method concerns primarily the use of violence (1970: 49), while he understands the Kingdom of God to be something different from political transformation, and the goal of the Zealots to be one of Jesus' temptations which he needed to resist (1970: 38-39).

Bosch's reflection on Jesus and the Zealots is continued from the work of Yoder, thus emphasizing that engaging in a forced change of society does not inaugurate something new (Bosch 1975b:5), while placing particular emphasis on the two aspects of critique which Cullmann presents: that the Zealots and those who adopt this position seek "mere change of government" (Bosch 1978:100) and that the way of Jesus rejects the use of force (Bosch 1975a:6).

So how does Bosch connect the option of the Zealots to the context of apartheid? He describes the Zealots as representing those who advocate a "theology of the revolution" (1982b:7) and makes a direct connection between the Zealots and liberation theology by stating that a theology of liberation mistakenly identifies Jesus completely with the Zealots (1975b:6). ${ }^{2}$ Perhaps Bosch's most explicit connection between the Zealots and apartheid is in a talk given to students of the University of South Africa. In response to a question posed by the students, "Who would Jesus vote for?", he reminds them that black ANC members are, at least formally,

1 Although Bosch (1975:4) recognizes that this group did not necessarily exist as an organized political group in the time of Jesus, he nonetheless continues to refer to them in his reflection. The question on historicity is not of concern in this article, but rather how this group impacted his reflection on Jesus and the church within the context of apartheid.

2 While Cullmann refrains from drawing lines between his analysis of Jesus and the Zealots and the contemporary situation (Cullmann 1970:52), he similarly refers to those who wish to make Jesus as Zealotist revolutionary (:34). 
NGTT: Oopbron - http://ngtt.journals.ac.za

closer to the position of Jesus than any of them, and that Black Theology identifies with the call for liberation in Luke 4 (Bosch 1981:2). He then draws a direct parallel between the ANC and the Zealots, saying "As die ANC in die meer onlangse verlede toenemend tot geweld oorgegaan het, dan redeneer hulle presies net soos die Selote van die eerste Christelike eeu"3 (Bosch 1981:10).

The constant reminder that the Zealots were those to whom Jesus stood closer than the other options might provide an analogy for how Bosch may have regarded his own stance in relation to that of the many close friends who identified with liberation theology. On a less personal level, we should, as will be discussed below, regard this as an analogy - albeit it an unfortunate one at times - for the relationship between the alternative community and liberation theology. The analogy points to Bosch identifying himself more with those who actively opposed the oppressive forces - the Apartheid government - than with the other options Bosch perceived to be available, such as withdrawing from society or attempting to collaborate with an unjust system. Yet he could not condone violence, was wary that liberation was being reduced to political change, and ultimately did not believe that the use of force will ever bring about a truly new order.

\section{The alternative community And Liberation theology}

Balcomb $(1989,1990)$ used Bosch as an example in his analyses of Third Way theologies in South Africa. But the brush Balcomb used to paint the landscape in that late hour of apartheid was a broad one. Third way theologies include "liberals" (1990:40-41), Nico Smith (1990:44-45) and Hermann Giliomee (1989:44). The strong pacifist commitment of Bosch and Yoder, a broad rejection of violence, including in particular the violence of the status quo ((Bosch 1991b:441), need not be a defining characteristic of Third Way approaches in the way Balcomb portrays them; on the contrary, Third Way approaches are suspected of being easily co-opted by the state and keeping the status quo in place.

In Balcomb's description of Bosch the emphasis rests on being an alternative on both the church as merely another social agency and the church's withdrawal from society, but incorrectly portray Bosch as an example of reinforcing the middle-ground power concerns. Nicol therefore revised Balcomb's interpretation, pointing out Bosch's constant opposition to apartheid, and stating that his position can better be described as "somewhere between a third way and a clear stand against oppression" (Nicol 1990:96). In a similar way yet with the benefit of hindsight Kritzinger \& Saayman (2011:186-189), in dialogue with Balcomb's analyses, describe Bosch's approach as indeed prophetic - clearly opposed to the oppression happening in South Africa - although choosing a different approach than liberation theologies.

The relationship between Jesus and the Zealots as described by Bosch and this description as an analogy for his own stance toward liberation theologies, can also be seen in how he responded to the Kairos document. While the Zealots are not explicitly mentioned, the form of his argument continues from his reflection on the Zealots. Although he chose not to sign the Kairos Document, he later wrote: "Since it was first published I have, however, begun to have second thoughts about the matter. I still have not signed it but I am today closer to it than I've been before." (Bosch 1987:15)

3 "When the ANC, in their more recent past, increasingly turned to violence, then they are arguing exactly like the Zealots from the first Christian century" 
NGTT Deel 54, Nommers $3 \& 4$, September en Desember 2013

His reasons for not signing Kairos follow his reflections on the relationship between Jesus and the Zealots, and reveal the unfortunate equation of liberation theology with his image of the Zealots. Firstly, he considered Kairos to offer no other form of salvation than political liberation. Although his explicit question was concerned with what would happen if this liberation did not come, he had often in the past indicated that even if a particular revolutionary group would be able to successfully undermine the status quo, the church cannot commit itself without reserve to such a revolution either. Secondly, he considered the Kairos document to have a tacit support for revolutionary violence, or at least that it suggested that responding with violence to violence is inevitable (Bosch 1987:15). His problems with the Kairos document are therefore similar to the difference between Jesus and the Zealots which he adopted from Yoder and Cullmann in the 1970's, focusing on what he interpreted as Kairos's exclusive emphasis on political liberation and the legitimization of violence.

Kritzinger and Saayman (2011:100-101) argue that Bosch misunderstood the intention of the Kairos signatories, and that he had misread the situation in South Africa. The intention was not to support violence, but rather to highlight the importance of finding a solution without delay. And history has proven that political change was indeed closer than many expected at that time. But underlying this misunderstanding there is a deeper question concerning the interpretation of liberation theology. For Bosch, liberation theology is seen as singlemindedly concerned with political liberation. In this way the analogy of Jesus and the Zealots becomes an unfortunate one, reducing liberation theology to a narrow theology exclusively accompanying movements for political liberation which seek governmental change, even if this should require revolutionary violence. He consistently critiques liberation theology by looking through this lens.

The essence of Bosch's (1991b:429-430) interpretation of liberation theology seems to be captured in his view of Nolan as a liberation theologian who makes a very direct connection between the political struggle in South Africa and the work of God, anticipating a utopian future introduced by the struggle. While in Transforming Mission he sketches positive (from his point of view) developments in liberation theology, where the utopianism starts to disappear and the church is more central, this contrast again confirms his interpretation of the initial phases of liberation theology. Furthermore, it should be noted that while he recognizes South African liberation theology which is committed to nonviolence, his more positive interpretation of integral liberation is exclusively focussed on Latin American liberation theology (Bosch 1991b:442-447).

While much has been said about the relationship between Bosch and liberation theology over the past decades, the image of Jesus and the Zealots might help further illuminate where Bosch would have seen himself in the struggle against apartheid. Bosch's later vision for the church under apartheid provides an important perspective. He describes the task of the church as "to find a way of resolutely showing solidarity with the poor and the oppressed while at the same time preaching and practising a transcendent love. Unless it follows this course, the spectre of violence and ruin and hatred will always be with us, both now and after liberation" (Bosch 1987:16). This short statement closely reflects his use of Yoder sketched above:

- $\quad$ emphasizing that political liberation might not bring about true liberation, since we will continue in violence

- describing the love of enemies as central in overcoming the cycle of violence 
NGTT: Oopbron - http://ngtt.journals.ac.za

- $\quad$ placing the relationship with the poor and oppressed central to his approach.

It can perhaps best be described by saying that he saw the alternative community standing close to the liberation movements, agreeing with them that the church has a particular calling to stand up against oppression, yet holding to the belief that this is best done by becoming an alternative community.

Yet in a posthumously published essay he states that:

"I would therefore suggest that, in spite of very real differences between the reformist, liberationist and anabaptist models, they are closer to each other than may appear at first glance. And it is gratifying to note that more and more scholars are detecting the fundamental affinity between them" (Bosch 1993:94).

But whereas he constantly sought to emphasize the similarities between Reformed and Anabaptist ecclesiology, and right after this statement refer to De Gruchy as an example of an attempt at seeking out the affinity between Reformed and Liberation theology, he fails to clearly point out the overlap between liberation theology and the alternative community. As Conradie (2011:93) points out, Bosch fails to expand on the relationship between reconciliation (which is the main soteriological element he associates with the church as alternative community) and liberation. In following Yoder he emphasizes that the reconciled community is the only way towards true liberation, but Bosch consistently fails to provide a concrete analysis concerning how this theological vision of a reconciled community would have an effect on the actual sociological liberation of people. This absence seems to be one of the key problems with Bosch's suggestion.

Elements for a dialogue between the church as alternative community and liberation theology, between Bosch's emphasis on reconciliation and the call for liberation, are indeed visible in his work, although never explored by Bosch. Bosch's consistent exposition of Luke 4 as a text which reveals the alternative which Jesus inaugurated (1977:13-15; 1991b:108-113), together with his recognition that this text is also at the heart of the liberation theologies (1981:2; 1984:3) might open up such a dialogue. This is again found when he states that the Bible should be read as an establishment-critical document (1984:3), again explicitly positioning himself closer to those who opposed the status quo than those who sought to maintain it. Saayman (2011:14) also shows the possible affinity when extending Bosch's logic of the church as alternative community to coincide with what a prophetic theology in the tradition of the Kairos Document would look like today.

We may remember Bosch as one who criticised liberation theology either in order to point out perceived limitations in his approach (an important aspect of critical engagement with his work, which has led to a deeper understanding of some of the pitfalls in his approach), or to justify our own rejection of liberation theology. In a world where liberation theology continues to be a contested notion, and theologies drawing on the work of Bosch often reveal either ignorance or a disregard for the continued importance of liberation theologies, ${ }^{4}$ there

4 See for example the scant reflection on liberation theologies in Van Gelder \& Zscheile (2011) overview of missional theology as well as Storrar's (2011) use of Bosch to define his approach to public theology, while limiting liberation theology largely to a context which precede a modern democracy. This can perhaps also be seen in the context of continued Dutch Reformed Church reflection on its role in South Africa, where the work of Bosch has become an important influence, yet liberation theology often continues to be ignored or rejected. 
NGTT Deel 54, Nommers $3 \& 4$, September en Desember 2013

is danger in a one-sided recollection of Bosch's critique on liberation theology, while ignoring the fact that he shared some basic concerns with liberation theology amidst apartheid. In as far as Bosch is used to relegate liberation theology to a distant past we need to accentuate the constant undercurrent in his work in which he acknowledges an overlap between Jesus and the struggle for liberation, to the extent that he would remind a group of Afrikaans students in 1981 that there is a closer connection between Jesus and the ANC, than between any of them and Jesus.

However, this aspect alone would paint a distorted picture of Bosch's view, as if the alternative community is defined purely by what it is not. The last section therefore briefly looks at how Bosch then envisioned the church as alternative community under apartheid.

\section{ThE LIFE OF THE ALTERNATIVE COMMUNITY}

Amidst the context of apartheid, the alternative community would be marked by radically transformed membership rules where the distinctions between "in-group" and "out-group" no longer matter (1977a:11-12), and where compassion, also towards our enemies, guides all our actions (1977a:26).

He emphasises that the church should focus on doing that which no other institution or group can do, and that this must be visibly distinguishable in the life of the church. One of these unique elements of the church is that she can pray for the world. But in order for the church to become an intercessor for the world, she needs to become that which she is praying for (Bosch 1975a:5). Similarly, when the church seeks to speak to society with a prophetic voice - whether in a process of nation-building or liberation - she needs to tangibly reflect the new community in her life and structures, otherwise it will be of no effect (Bosch 1978:100-101). It would be a mistake to reduce Bosch's alternative community to a church exclusively living a silent alternative (although this is to be preferred if the use of force is the only other option), but in his whole approach there can be no formative influence on society without a church which already lives from the values to which it calls society, thus a church as an alternative community which engages society.

Where do we find this alternative community under apartheid? Kritzinger and Saayman (2011:91) states that Bosch found it difficult to identify any such church groups in South Africa, and he himself states that no denomination will ever be such an alternative community (Seitz 1977:11). But at least one incident might reveal his imagination of the alternative community, a moment which kept alive his vision of the church as an alternative community under apartheid.

The PACLA ${ }^{5}$ experience left a deep mark in Bosch's imagination of how the church as an alternative community might contribute to change in South Africa. He drew on this example of black and white participants experiencing deep reconciliation at PACLA to motivate a similar event in South Africa (which later became SACLA), with the expressed hope that such an event would spark widespread reconciliation (Bosch 1977b:5-8). But what he implied by reconciliation within such an alternative community needs some clarification in our contemporary context where "reconciliation" has become such a widespread notion in South Africa, and perhaps also in his own context, where he later admitted that reconciliation was

5 PACLA (Pan African Christian Leadership Assembly) was a gathering of African church leaders held in Nairobi, Kenya from 9-19 December 1976. 
NGTT: Oopbron - http://ngtt.journals.ac.za

at times used to merely subdue people (Bosch 1987:15). To quote from his own contribution at PACLA:

“...reconciliation is no cheap matter. It does not come about by simply papering over deep seated differences. Reconciliation presupposes confrontation. Without that we do not get reconciliation, but merely a temporary glossing over of differences. The running sores of society cannot be healed with the use of sticking plaster. Reconciliation presupposes an operation, a cutting to the very bone, without anaesthetic. The infection is not just on the surface. The abscess of hate and mistrust and fear, between black and white, between nation and nation, between rich and poor, has to be slashed open."

(1978:101)

When speaking to the exiled ANC he reminded them that the settlement which might come in South Africa - and which in the end did come - would be fragile for years to come and would only be kept alive by means of many compromises (Bosch 1991a:17). At the same time he reminded the Dutch Reformed Church that repentance calls for restitution (Bosch 1991a:13). It would be a painful process for all involved. Real communication and costly reconciliation (Bosch 1977b:5) are the marks of the alternative community, and his choice to emphasize these aspects cannot be disconnected from the context of apartheid amidst which they emerged.

Finally we need to turn to the question constantly directed to Bosch: would the new community with new membership rules and a life of compassion, the community where real communication and costly reconciliation are core values and where they are visibly expressed, be able to bring about justice in society? Bosch provides two answers to this:

The first is that for him this is the wrong question. The church "is called to be faithful, not effective" (Bosch 1975a:6). His vision was not for a silent church, indeed the church should be a prophetic voice in society (Bosch 1975a:6), it should evaluate governments as good or bad (Bosch 1978:99) and its members should actively take part in practical politics (Bosch 1975a:7-8). But rather than lose its distinct nature as an inclusive and compassionate community, the church should revert to silence, challenging the status quo by its life together if no other option existed. As he told representatives of the civic community in Pietermaritzburg, "let us not lose heart when the world remains very much the same. The challenge to us is to remain faithful to the guiding principles of the "alternative community", irrespective of the outcome." (Bosch 1975a:8)

Secondly, the church should not overestimate its role. It becomes redundant and irrelevant when repeating that which other institutions and groups can do (Bosch 1975:3; 1979:224) and often tends to exceed its level of competence when announcing how the world must look (Bosch 1991b:387). Furthermore, it is not the church's task to inaugurate utopia in history (Bosch 1991b:509). The task of the church is therefore limited to that which flows from the life of the alternative community while recognizing that the work of God is much broader than the church (Bosch 1982c:142)

In these answers we are again without a concrete analysis of how the alternative community will bring about social change. Bosch refrains from providing such a concrete analysis, rather leaving it to the local church to discern what being an alternative should be. In exploring this, a deeper dialogue on how the church as an alternative community might become a liberating community in its various contexts remains important. We need to continuously break the silence between the church as alternative community and liberation theology. 
NGTT Deel 54, Nommers $3 \& 4$, September en Desember 2013

\section{CONCLUSION}

Perhaps the choice to reflect on the relationship between Jesus and the Zealots, between Bosch and liberation theology, is born out of my own critical struggle with the collective memory of my own community. Within the Dutch Reformed Church Bosch will remain (or is that rather "became"?) an important voice. But it is too easy to call Bosch "one of us", appreciating his critique on revolutionary violence, while tacitly supporting the violence of the status quo, whether that is police brutality and the excessive use of force or the violence of economic exclusion. It is too easy to repeat the call for reconciliation, while remaining silent about his insistence on restitution and the cost of reconciliation.

While the tension between Bosch and liberation theology has often been reflected upon by those in the tradition of South African liberation theology, there is at times a fading memory of the way in which Bosch seems to have experienced himself as standing alongside liberation theology and liberation movements, seen in his analogy of Jesus and the Zealots.

And so I sought to remember the relation between Jesus and the Zealots; not only as a reminder that for Bosch political liberation can never inaugurate utopia and that the churches can never commit itself to any political organization without reservation, but more importantly in this case, as a reminder that for Bosch Jesus might have been closer to the freedom fighters than those of us in today's white Afrikaans Reformed churches may be comfortable with. While we like to remember Bosch's emphasis on unity, we are hesitant to insist that repentance calls for restitution. In such a one-sided interpretation David Bosch runs the danger of being reinterpreted as a "safe" theologian, envisioning an alternative community which can continue without a slashing open of "the abscess of hate and mistrust and fear".

\section{BiBLIOGRAPHY}

Ahonen, T. 2003. Transformation through compassionate mission. David J. Bosch's theology of contextualization. Helsinki: Luther-Agricola Society.

Balcomb, A. 1989. Third way theologies in the contemporary South African situation - towards a definition and critique. Journal of Theology for Southern Africa 68:41-60.

Balcomb, A. 1990. Third way theologies in the contemporary South African situation, in Hofmeyr, M. Kritzinger, J.N.J. \& Saayman, W. (eds.) Wit Afrikane?'n gesprek met Nico Smith. Bramley: Taurus, 33-46.

Bekele, G 2011. The in-between people. A reading of David Bosch through the lens of mission history and contemporary challenges in Ethiopia. Oregon: Pickwick Publications.

Bosch, D.J. 1975a. The alternative community. Unpublished paper read at the church and society dinner, Pietermaritzburg, 19 September 1975.

Bosch, D.J. 1975b. The church as the "alternative community". Journal of Theology for Southern Africa, 13:3-11.

Bosch, D.J. .1977a. Die nuwe gemeenskap. Unpublished paper read at Reveil event, 22 January 1977.

Bosch, D.J. 1977b. The inbetween people. Unpublished paper.

Bosch, D.J. 1978. Renewal of Christian community in Africa today, in Facing the new challenges - The message of PACLA, December 9-19, 1976, Nairobi. Kisumu, Evangel Publishing House, 92-102.

Bosch, D.J. 1979. Heil vir die wêreld: Die Christelike sending in teologiese perspektief. Pretoria: N.G. KerkBoekhandel.

Bosch, D.J. 1981. Jesus: NAT? PROG? ANC? .Unpublished paper, read at SCA meeting, University of Pretoria, 2 April 1981

Bosch, D.J 1982a. How my mind has changed. Mission and the alternative community. Journal of Theology for Southern Africa 41:6-10.

Bosch, D.J 1982b. The church as the alternative community. Potchefstroom: Instituut vir Reformatoriese 
NGTT: Oopbron - http://ngtt.journals.ac.za

Studie.

Bosch, D.J. 1982c. In gesprek met Dr P.F. Theron, in Bosch D.J. König A. \& Nicol W. (eds.) Perspektief op die Ope Brief. Pretoria: Human \& Rousseau, 134-142.Bosch D.J. 1983a. "Nothing but a heresy" in De Gruchy J. \& Villa-Vicencio, C. (eds.) Apartheid is a heresy. Cape Town: David Philip, 24-38.

Bosch, D.J. 1983b. Religion and state: Five models. Unpublished paper.

Bosch, D.J. 1984. Opening: Symposium on "sexism and feminism in theological perspective". Unpublished paper at the eighth symposium of the Institute for Theological Research (UNISA) on 5-6 September 1984.

Bosch, D.J. 1987. The Christian church in a revolutionary situation. Unpublished paper.

Bosch, D.J. 1991a. The role of the church in a new South Africa. Unpublished paper.

Bosch, D.J. 1991b. Transforming mission: Paradigm shifts in theology of mission. Maryknoll, N.Y.: Orbis Books.

Bosch, D.J. 1993. God's reign and the rulers of this world, in C. Van Engen, D.S. Gilliland and P. Pierson, eds. The Good news of the kingdom: Mission theology for the third millennium. Maryknoll, N.Y.: Orbis Books.

Botha, N.A. 2011. Transforming missiology: A dialogue with some reviewers of David Bosch's Transforming mission. Missionalia 39 (1/2):18-31.

Conradie, E.M. 2011. Missiology and soteriology: The power and limits of a multidimensional approach. Missionalia 39 (1/2):82-98.

Cullmann, O. 1970. Jesus and the revolutionaries. New York: Harper \& Row.

Guder, D.L. \& Reppenhagen, M. 2011. Conclusion to the anniversary edition: The continuing transformation of mission: David Bosch's living legacy 1991-2011 in Bosch, D.J. Transforming mission: Paradigm shifts in theology of mission. 20th anniversary edition. Maryknoll, N.Y.: Orbis Books, 533-555.

Kritzinger, J.N.J. \& Saayman, W. 2011. David J. Bosch. Prophetic integrity, cruciform praxis. Pietermaritzburg: Cluster Publications.

Nicol, W. 1990. The cross and the hammer: comparing Bosch and Nolan on the role of the church in social change, in Kritzinger J.N.J. \& Saayman, W. (eds). Mission in creative tencion. A dialogue with David Bosch. Pretoria: S.A. Missiological Society, 86-98.

Saayman, W. 2011. Alternative community and antibody: A dimension of David Bosch as public theologian. Missionalia 39 (1/2):5-17.

Seitz, R. 1977. A critic within. In The Church Herald, 13 May 1977, 10-11

Storrar, W. 2011. The naming of parts: Doing public theology in a global era. International Journal of Public Theology 5(1):23-43.

Van Gelder, G. \& Zscheile D.J. 2011. The missional church in perspective. Mapping trends and shaping conversations. Grand Rapids: BakerAcademic.

Van Wyngaard, G.J. 2011 The public role of the Christian community in the work of David Bosch. Missionalia 39 (1/2):151-166.

Yoder, J.H. 1972. The original revolution. Essays on Christian pacifism. Scottdale: Herald Press.

\section{KEY WORDS}

David Bosch

Anabaptism

Liberation Theology

Alternative Community

Apartheid

\section{TREFWOORDE}

David Bosch

Anabaptisme

Bevrydingsteologie

Alternatiewe Gemeenskap

Apartheid 
NGTT Deel 54, Nommers 3 \& 4, September en Desember 2013

\section{Contact details}

George Jacobus (Cobus) van Wyngaard

Research Assistant

University of South Africa, Department of Philosophy, Practical and Systematic Theology South Africa 